\title{
Effects of three slow-release urea inclusions in rice straw-based diets on yearling Bali bull performances
}

\author{
D. Kardaya ${ }^{1 \#}$, K.G. Wiryawan ${ }^{2}$, A. Parakkasi ${ }^{2}$ \& H.M. Winugroho ${ }^{3}$ \\ ${ }^{1}$ Department of Animal Sciences, Djuanda University, Box 35, Bogor 16720, Indonesia \\ ${ }^{2}$ Department of Animal Nutrition and Feed Technology, Bogor Agriculture University, IPB Bogor, Indonesia \\ ${ }^{3}$ Indonesian Research Institute for Animal Production, Box 221 Bogor 16002, Indonesia
}

(Received 27 October 2017; Accepted 16 July 2018; First published online 9 September 2018)

\author{
Copyright resides with the authors in terms of the Creative Commons Attribution 4.0 South African License. See: \\ http://creativecommons. org/licenses/by/4.0/za \\ Condition of use: The user may copy, distribute, transmit and adapt the work, but must recognize the authors and the South African \\ Journal of Animal Science.
}

\begin{abstract}
The effects of slow-release zinc-urea complexes (ZnU), urea-impregnated zeolite (UZ) and zinc-ureaimpregnated zeolite (ZnUZ) on the performance of yearling Bali bulls were assessed using 20 Bali bulls $(145.3 \pm 2.5 \mathrm{~kg}$ bodyweight $(\mathrm{BW}))$, which were allocated to five treatments and four replications in a completely randomized design. The treatments were: Diets supplemented with no urea (NU) and with urea $(\mathrm{U}), \mathrm{ZnU}, \mathrm{UZ}$ and $\mathrm{ZnUZ}$. The results of the in vivo study revealed that both $\mathrm{ZnU}$ and $\mathrm{UZ}$ might replace urea effectively by increasing feed intake. Moreover, substituting urea with ZnU, UZ or ZnUZ increased crude protein total tract apparent digestibility whereas $\mathrm{ZnU}$ or UZ replacing urea, improved fibre total tract apparent digestibility. Furthermore, inclusion of $U Z$ in the diet improved live weight gain and feed efficiency in Bali bulls above that of the $U$ and NU diets. Thus, the inclusion of $Z n U Z$ in rice straw-based diets showed slow-release urea had positive impacts on feed intake and nutrient digestibility, and increased the efficiency of feed utilization in Bali bulls.
\end{abstract}

Keywords: Apparent digestibility, feed intake, urea-impregnated zeolite, zinc

\#Corresponding author: dede.kardaya@unida.ac.id

\section{Introduction}

The use of urea as an effective and inexpensive nitrogen $(\mathrm{N})$ source for ruminants has increased in recent years. However, it is generally accepted that urea is rapidly hydrolysed into ammonia by rumen microbes and generates negative influences on the rumen system. Therefore, many investigations focused on reducing its negative effects. Ludden et al. (2000a, 2000b) used N-(n-butyl) thiophosphoric triamide; Kardaya et al. (2000) and Kathirvelan \& Balakrishnan (2006) experimented with zinc compounds, Golombeski et al. (2006) tried a Ca-urea compound and Taylor-Edwards et al. (2009a, 2009b) used polymercoated urea as slow-release urea agents. Other researchers (Bosi et al., 2002; Koknaroglu et al., 2006; Migliorati et al., 2007) used zeolite to reduce the rate of urea hydrolysis in the rumen system. In addition, Mentz et al. (2015) applied Optigen ${ }^{\circledR}$ II as a slow-release N source for sheep. Most tropical forages are regarded as being of low quality. This is especially true of agriculture waste products such as rice straw. Ruminal carbohydrate degradation of rice straw is a slow process, which needs synchronizing with rumen microbial $\mathrm{N}$ usage. To achieve greater synchrony of these processes, newer forms of slow-release urea compounds (zinc-urea complex, urea-impregnated zeolite and zinc-urea impregnated zeolite (ZnUZ)) were introduced by Kardaya et al. $(2009 ; 2010)$ to reduce the rate of urea release in the rumen system in in vitro studies. However, no investigation has examined the effects of these slow-release urea compounds on ruminant performance as such. Therefore, it is imperative that the slow-release urea compounds should be evaluated under in vivo situations. An investigation was conducted to determine the effects of supplementing rice straw-based diets with slow-release urea on feed intake, apparent digestibility of nutrients and growth performances of yearling Bali bulls.

\section{Materials and Methods}

Twenty yearling Bali bulls (Bos sundaicus) with an initial body weight (BW) of $145.3 \pm 2.5 \mathrm{~kg}$ were used in a completely randomized experimental design with five dietary treatments and four replicates, to 
measure their intake, digestibility of nutrients and performance in a feedlot. The bulls were randomly assigned to five treatments (four bulls per treatment), and housed in 20 pens with one bull per pen (3.15 $\left.\mathrm{m}^{2}\right)$. The basic experimental diet (Table 1) contained $45 \%$ chopped rice straw (8-10 cm in length) and $55 \%$ concentrates (dry matter (DM) basis). Five experimental treatments were used: A control containing no urea (NU) but soybean meal and coconut meal and as the main sources of protein, and four treatments where urea replaced some of the plant protein sources, and was included as urea (U), a slow-release zinc-urea complexes (ZnU), urea-impregnated zeolite (UZ) and zinc-urea-impregnated zeolite (ZnUZ). These slowrelease urea compounds have been evaluated in in vitro studies (Kardaya et al., 2009; 2010). All urea containing diets were formulated to contain the same crude protein (CP) level with a urea content of $1.43 \%$ which supplied $33 \%$ of total CP.

Table 1 Feed composition and nutrient composition of the experimental diets fed to yearling Bali bulls

\begin{tabular}{|c|c|c|c|c|c|}
\hline \multirow{2}{*}{ Item } & \multicolumn{5}{|c|}{ Diets (DM basis, \%)* } \\
\hline & NU & $\mathbf{U}$ & ZnU & UZ & ZnUZ \\
\hline \multicolumn{6}{|l|}{ Ingredients, \% DM basis } \\
\hline Rice straw & 45.00 & 45.00 & 45.00 & 45.00 & 45.00 \\
\hline Corn, crack & 2.00 & 4.00 & 4.00 & 4.00 & 4.00 \\
\hline Rice bran & 13.00 & 13.00 & 10.00 & 9.59 & 9.59 \\
\hline Soybean meal & 5.00 & - & - & - & - \\
\hline Cassava meal & 10.48 & 15.05 & 16.12 & 15.00 & 15.00 \\
\hline Coconut meal & 24.00 & 15.00 & 16.00 & 16.12 & 16.14 \\
\hline Molasses & - & 6.00 & 6.00 & 6.00 & 6.00 \\
\hline Premix $†$ & 0.10 & 0.10 & 0.10 & 0.10 & 0.10 \\
\hline Dicalcium phosphate & 0.40 & 0.40 & 0.40 & 0.40 & 0.40 \\
\hline ZnSO4 & 0.02 & 0.02 & - & 0.02 & - \\
\hline Urea & - & 1.43 & & & \\
\hline Zinc-urea & - & - & 2.38 & & \\
\hline Urea-impregnated zeolite & - & - & & 3.77 & \\
\hline Zinc-urea-impregnated zeolite & - & - & & & 3.77 \\
\hline \multicolumn{6}{|l|}{ Nutrient composition, \% DM basis } \\
\hline Crude protein & 12.91 & 11.66 & 12.20 & 12.18 & 12.10 \\
\hline Extract ether & 6.03 & 4.95 & 4.17 & 4.52 & 3.81 \\
\hline Crude fibre & 18.00 & 17.73 & 17.55 & 17.37 & 16.60 \\
\hline Nitrogen-free extracts & 50.58 & 53.07 & 53.67 & 53.00 & 54.78 \\
\hline Ash & 12.48 & 12.59 & 12.41 & 12.93 & 12.72 \\
\hline Calcium & 0.10 & 0.12 & 0.11 & 0.13 & 0.13 \\
\hline Phosphorus & 0.04 & 0.06 & 0.07 & 0.07 & 0.07 \\
\hline Zinc, mg/kg & 34.85 & 33.75 & 34.30 & 33.75 & 34.85 \\
\hline Neutral detergent fibre & 52.68 & 50.81 & 48.61 & 51.48 & 48.84 \\
\hline Acid detergent fibre & 34.45 & 34.88 & 33.81 & 34.47 & 34.05 \\
\hline Cellulose & 21.89 & 22.33 & 21.66 & 21.98 & 21.41 \\
\hline Lignin & 4.56 & 4.05 & 4.03 & 4.65 & 4.08 \\
\hline Hemicellulose & 18.23 & 15.94 & 14.80 & 17.01 & 14.79 \\
\hline Silica & 8.17 & 8.11 & 8.13 & 8.27 & 8.29 \\
\hline Total digestible nutrients & 60.07 & 59.44 & 60.47 & 59.73 & 59.62 \\
\hline
\end{tabular}

\footnotetext{
* NU: no urea; U: urea; ZnU: zinc-urea; UZ: urea-impregnated zeolite; ZnUZ: zinc-urea-impregnated zeolite; urea $\mathrm{N}$ represented $33 \%$ of total $\mathrm{N}$; ‡ Total digestible nutrients $=0.67 \times$ DM (NRC 1985)

† Composition (per kg): vit. A 500000 IU, vit. D 100000 IU, vit. E 150 mg, L-lysine 3750 mg; DL-methionine 5000 mg, magnesium $1700 \mathrm{mg}$, iron $1250 \mathrm{mg}$, manganese $2500 \mathrm{mg}$, copper $25 \mathrm{mg}$, iodine $5 \mathrm{mg}$, zinc $500 \mathrm{mg}$
} 
The experiment was conducted over 67 days (14 days for diet adaptation, 56 days for feed intake and growth trial, and 7 days a nutrient digestibility study). Bulls were weighed biweekly before morning feeding. Feed refusals (rice straw and concentrates) were weighed every morning at 07:00 before morning feeding. The bulls were fed twice daily (08:00 and 16:00) at 3\% BW (DM basis). The amount of the feed was adjusted biweekly for changes in BW. Water was provided ad libitum.

Feed and feed refusals were collected, sub-sampled $(100 \mathrm{~g})$ and dried $\left(55^{\circ} \mathrm{C}, 96 \mathrm{~h}\right)$ each week. The weekly samples were composited for each bull, sub-sampled again (100 g), ground through a 1-mm screen in a Willey mill and frozen $\left(-4{ }^{\circ} \mathrm{C}\right)$, pending analysis. Samples were analysed for DM (AOAC, 1990), organic matter (OM) (determined by ash), CP (obtained by total $\mathrm{N}$ determination using the micro-Kjeldahl technique and calculated as $\mathrm{N} \times 6.25$ ) and ether extract (EE) (determined gravimetrically after extraction using petroleum ether in a Soxhlet instrument) (AOAC, 1990). Furthermore, neutral detergent fibre (NDF) was determined according to the procedures of Van Soest et al. (1991), acid detergent fibre (ADF), using the AOAC method (1990) and sulphuric acid lignin according to the procedure of Robertson \& Van Soest (1981).

Feed was weighed daily just before morning feeding. During a seven-day collecting period (from days 61 to 67 ) feed refusals and faeces were collected daily at 07:00 before morning feeding and was used to calculate nutrient digestibility. Total daily feed refusals were weighed, sub-sampled, dried $\left(55^{\circ} \mathrm{C}, 96 \mathrm{~h}\right)$, and stored $\left(-4{ }^{\circ} \mathrm{C}\right)$ for analysis. Faeces was collected several times daily and stored in plastic containers. Total daily faecal output was weighed, sub-sampled $(5 \%)$, dried $\left(55^{\circ} \mathrm{C}, 96 \mathrm{~h}\right)$ and stored $\left(-4{ }^{\circ} \mathrm{C}\right)$ for analysis. Feed, feed refusals and faecal samples were analysed in duplicate for DM (AOAC, 1990), OM, CP, EE, NDF, ADF and sulphuric acid lignin according to the methods used in the feed analysis. Digestibility of nutrients was calculated as:

Digestibility, $\%=\{100 \times(\mathrm{g}$ of dietary intake $-\mathrm{g}$ of faecal nutrient $) /(\mathrm{g}$ of dietary intake $)\}$

All data were subjected to a one-way ANOVA and Duncan's multiple range test (Steel \& Torrie, 1980) using an SPSS application (Release 16.0, Chicago, IL, USA). Significant differences were measured within $P$ $<0.05$.

\section{Results}

Experimental diets (Table 1) supplied nutrients in relatively similar quantities to all bulls. However, the use of urea as a non-protein nitrogen (NPN) source to replace some of the $\mathrm{N}$ of soybean meal and coconut meal resulted that the EE and NDF levels of the NU diet were slightly higher than in the urea containing diets. Adding molasses to all urea supplemented diets increased their nitrogen free extract (NFE) levels slightly. Thus, all diet are assumed to supply equivalent levels of energy to the bulls.

The experimental diets affected $(P<0.05)$ dry matter intake (DMI) of the bulls: Including slow-release urea in the diets did not affect DMI, though including urea in treatment $U$ decreased $(P<0.05) \mathrm{DMI}$ compared to the control (Table 2). The replacing $U$ with $\mathrm{ZnU}$ and $\mathrm{UZ}$ increased $(P<0.05) \mathrm{DMI}$, but not when $\mathrm{ZnUZ}$ replaced the urea in treatment $U$.

When diet ingredients were separated individually into those of rice straw and concentrate, it was found that the concentrate intake fluctuated across the experimental diets, whereas rice straw intakes were similar. The DMI responses of the bulls, which were measured as percentage of BW (\% BW) and metabolic weight $\left(\mathrm{g} \mathrm{DM} / \mathrm{kg} \mathrm{BW}^{0.75}\right)$ showed no difference across experimental diets. However, nutrient intakes, except for ADF, were influenced $(P<0.05)$ by experimental diet. Intakes of OM, CP, NDF and hemicellulose were higher in the control (NU) than in the $U$ treatment $(P<0.05)$, but not cellulose intake. The OM intake was higher $(P<0.05)$ in the $\mathrm{ZnU}$ treatment than in the $U$ treatment, whereas CP intake was found to higher again in the slow-release urea diets. Both NDF and hemicellulose intakes were higher $(P<0.05)$ when $U$ was replaced with $\mathrm{UZ}$, while hemicellulose intake decreased $(P<0.05)$ when urea $(U)$ diet was replaced with $\mathrm{ZnU}$ and ZnUZ in the diets.

In the present study the experimental diets affected $(P<0.05)$ the apparent digestibility of the nutrients in the bulls (Table 3). Compared to the control diet (NU) the inclusion of urea (U treatment) did not change the digestibility of DM, OM, cellulose, hemicellulose and CP, but decreased NDF and ADF digestibility. Hemicellulose and CP digestibility increased $(P<0.05)$ in the zinc-urea $(\mathrm{ZnU})$ treatment compared to the control (NU), but not the digestibility of the other nutrient. The digestibility of all nutrients except that of NDF and ADF was higher $(P<0.05)$ in urea-impregnated zeolite $(U Z)$ treatment than in the control. In the zincurea-impregnated zeolite (ZnUZ) diet CP digestibility was higher than in the NU diet, while DM, OM, cellulose and hemicellulose digestibility were similar, but NDF and ADF digestibility were lower. Comparing the digestibility of nutrients in the $U$ treatment with those in the diets containing slow-release urea compounds, the digestibility of all nutrients except that of OM were higher in the SRU and $\mathrm{ZnU}$ treatments than in the $U$ 
treatment. All nutrients showed higher digestibility in the UZ treatment than in the urea $(U)$ treatment but in the ZnUZ treatment only DM and CP digestibility were higher, and not that of the other nutrient.

Table 2 Dry matter and nutrient intake of yearling Bali bulls during the experimental period

\begin{tabular}{|c|c|c|c|c|c|c|c|c|}
\hline \multirow{2}{*}{ Dry matter intake ${ }^{\dagger}$} & \multicolumn{5}{|c|}{ Diets (DM basis)* } & \multirow{2}{*}{ Mean } & \multirow{2}{*}{ SEM } & \multirow{2}{*}{$P$} \\
\hline & NU & $u$ & $\mathrm{ZnU}$ & UZ & ZnUZ & & & \\
\hline Feed, g/d & $4,164^{b}$ & $4,053^{\mathrm{a}}$ & $4,230^{b}$ & $4,156^{b}$ & $4,140^{\mathrm{ab}}$ & 4,149 & 15.61 & 0.001 \\
\hline Rice straw, g/d & 1,936 & 1,940 & 1,987 & 1,924 & 1,919 & 1,941 & 8.66 & 0.077 \\
\hline Concentrate, g/d & $2,228^{b}$ & $2,113^{\mathrm{a}}$ & $2,243^{b}$ & $2,232^{b}$ & $2,221^{b}$ & 2,207 & 13.70 & 0.003 \\
\hline$\% \mathrm{BW}$ & 2.30 & 2.25 & 2.27 & 2.26 & 2.23 & 2.26 & 0.01 & 0.088 \\
\hline $\mathrm{g} / \mathrm{kg} \mathrm{BW}^{0.75}$ & 82.44 & 82.47 & 83.27 & 83.74 & 84.29 & 83.24 & 0.25 & 0.053 \\
\hline \multicolumn{9}{|l|}{ Nutrient intakes ${ }^{\dagger}$, g/d } \\
\hline Organic matter & $3,637^{\mathrm{bc}}$ & $3,529^{a}$ & $3,695^{c}$ & $3,612^{\mathrm{abc}}$ & $3,606^{\mathrm{ab}}$ & 3,616 & 14.51 & 0.000 \\
\hline Crude protein & $537.41^{d}$ & $472.76^{a}$ & $516.01^{\mathrm{c}}$ & $506.36^{\mathrm{bc}}$ & $501.08^{b}$ & 506.72 & 4.94 & 0.000 \\
\hline NDF & $2193^{c}$ & $2059^{a}$ & $2056^{a}$ & $2139^{b}$ & $2022^{\mathrm{a}}$ & 2094 & 15.03 & 0.000 \\
\hline ADF & 1434 & 1413 & 1430 & 1432 & 1410 & 1424 & 3.78 & 0.095 \\
\hline Cellulose & $911^{\mathrm{b}}$ & $905^{\mathrm{ab}}$ & $916^{\mathrm{b}}$ & $913^{b}$ & $886^{\mathrm{a}}$ & 906 & 3.08 & 0.003 \\
\hline Hemicellulose & $759^{d}$ & $646^{\mathrm{b}}$ & $626^{a}$ & $707^{\mathrm{c}}$ & $612^{\mathrm{a}}$ & 670 & 12.70 & 0.000 \\
\hline
\end{tabular}

${ }^{\top}$ Different superscripts within rows differed significantly $(P<0.05)$

*NU: no urea; U: urea; ZnU: zinc-urea; UZ: urea-impregnated zeolite; ZnUZ: zinc-urea-impregnated zeolite

SEM: standard error of mean; NDF: neutral detergent fibre; ADF: acid detergent fibre

Table 3 Apparent digestibility of nurients of experimental diets fed to yearling Bali bulls

\begin{tabular}{|c|c|c|c|c|c|c|c|c|}
\hline \multirow{2}{*}{$\begin{array}{l}\text { Apparent } \\
\text { digestibility }^{\dagger}, \%\end{array}$} & \multicolumn{5}{|c|}{ Diets (DM basis)* } & \multirow{2}{*}{ Mean } & \multirow{2}{*}{ SEM } & \multirow{2}{*}{$P$} \\
\hline & NU & U & $\mathrm{ZnU}$ & UZ & ZnUZ & & & \\
\hline Dry matter & $67.30^{\mathrm{ab}}$ & $65.85^{a}$ & $69.35^{\mathrm{bc}}$ & $71.07^{c}$ & $69.16^{\mathrm{bc}}$ & 68.55 & 0.461 & 0.000 \\
\hline Organic matter & $68.79^{\mathrm{a}}$ & $68.75^{\mathrm{a}}$ & $70.60^{a b}$ & $72.23^{b}$ & $70.13^{\mathrm{ab}}$ & 70.10 & 0.378 & 0.004 \\
\hline NDF & $63.27^{\mathrm{b}}$ & $58.91^{a}$ & $63.33^{\mathrm{b}}$ & $65.32^{\mathrm{b}}$ & $58.63^{\mathrm{a}}$ & 61.89 & 0.657 & 0.000 \\
\hline ADF & $55.36^{\mathrm{b}}$ & $49.96^{a}$ & $54.24^{\mathrm{b}}$ & $56.25^{\mathrm{b}}$ & $50.36^{a}$ & 53.23 & 0.667 & 0.000 \\
\hline Cellulose & $72.03^{\mathrm{ab}}$ & $71.37^{\mathrm{a}}$ & $73.51^{\mathrm{bc}}$ & $75.36^{c}$ & $73.03^{\mathrm{ab}}$ & 73.06 & 0.361 & 0.000 \\
\hline Hemicellulose & $78.22^{\mathrm{a}}$ & $78.51^{\mathrm{a}}$ & $84.09^{b}$ & $83.71^{\mathrm{b}}$ & $77.65^{a}$ & 80.44 & 0.663 & 0.000 \\
\hline Crude protein & $71.19^{\mathrm{a}}$ & $71.79^{\mathrm{a}}$ & $75.13^{\mathrm{b}}$ & $74.93^{b}$ & $74.27^{b}$ & 73.46 & 0.426 & 0.000 \\
\hline
\end{tabular}

${ }^{\top}$ Different superscript within rows differ significantly $(P<0.05)$

*NU: no urea; U: urea; ZnU: zinc-urea; UZ: urea-impregnated zeolite; ZnUZ: zinc-urea-impregnated zeolite.

SEM: standard error of mean; NDF: neutral detergent fibre; ADF: acid detergent fibre

The experimental diets influenced $(P<0.05)$ final weight, live weight gain $(L W G)$, average daily gain (ADG) and feed efficiency (Table 4). Compared to the control (NU), the urea containing diet $(U)$ did not change the performance parameters of the bulls. In the case of slow-release urea compounds, both ZnU and ZnUZ improved $(P<0.05)$ weight gain above that of the urea $(U)$ containing diet, but did not change other performance parameters. Live weight gain, ADG and feed efficiency in the urea-impregnated zeolite (UZ) treatment were improved $(P<0.05)$ above that of the urea $(U)$ containing diet. 


\section{Discussion}

Total feed intake differed between treatments owing to differences in amounts of concentrates consumed. Animals receiving the diet containing urea $(U)$ had a lower DMI than those on the control (NU) diet. It is suggested that the poor palatability of urea could be the reason for this reduced intake, because Golombeski et al. (2006) previously reported that a decrease in feed intake in a urea treatment was caused by the bitter taste of urea. In the current study, the increased DMI responses of the bulls receiving the ZnU and $U Z$ containing diets compared with those on the urea $(U)$ diet suggested that these complexes improved the palatability problem of untreated urea, as found by Golombeski et al. (2006).

Table 4 Performances of yearling Bali bulls fed different sources of urea

\begin{tabular}{|c|c|c|c|c|c|c|c|c|}
\hline \multirow{2}{*}{ Performances $^{\dagger}$} & \multicolumn{5}{|c|}{ Diets (DM basis) } & \multirow{2}{*}{ Mean } & \multirow{2}{*}{ SEM } & \multirow{2}{*}{$P$} \\
\hline & NU & u & $\mathrm{ZnU}$ & UZ & ZnUZ & & & \\
\hline Initial weight, kg & 147.25 & 145.75 & 150.50 & 146.50 & 148.75 & 147.75 & 0.615 & 0.087 \\
\hline Final weight, kg & $181.25^{\mathrm{ab}}$ & $180.00^{\mathrm{a}}$ & $186.75^{\mathrm{c}}$ & $183.75^{\mathrm{abc}}$ & $185.25^{\mathrm{bc}}$ & 183.40 & 0.723 & 0.004 \\
\hline Live weight gain, kg & $34.00^{\mathrm{a}}$ & $34.25^{\mathrm{a}}$ & $36.25^{\mathrm{ab}}$ & $37.25^{\mathrm{b}}$ & $36.50^{\mathrm{ab}}$ & 35.65 & 0.399 & 0.013 \\
\hline Average daily gain, $\mathrm{g}$ & $606.75^{\mathrm{a}}$ & $611.25^{\mathrm{a}}$ & $646.75^{\mathrm{ab}}$ & $664.50^{\mathrm{b}}$ & $651.25^{\mathrm{ab}}$ & 636.10 & 7.092 & 0.013 \\
\hline \multicolumn{9}{|l|}{ Feed efficiency: } \\
\hline kg LWG/kg DMI & $0.146^{\mathrm{a}}$ & $0.151^{\mathrm{ab}}$ & $0.153^{\mathrm{abc}}$ & $0.160^{\mathrm{c}}$ & $0.157^{\mathrm{bc}}$ & 0.153 & 0.002 & 0.017 \\
\hline
\end{tabular}

${ }^{\top}$ Different superscripts within the same row differ significantly $(P<0.05)$

*NU: no urea; U: urea; ZnU: zinc-urea; UZ: urea-impregnated zeolite; ZnUZ: zinc-urea-impregnated zeolite.

SEM: standard error of mean. LWG: liveweight gain; DMI: dry matter intake

Other studies (Forero et al., 1978; Galina et al., 2003) reported increased feed intakes when coated urea replaced pure urea. However, Galo et al. (2003) and Taylor-Edwards et al. (2009b) reported that polymer-coated urea substituting urea did not alter feed intake significantly. It was more likely that the slowrelease urea properties of $\mathrm{ZnU}$ and $\mathrm{UZ}$ in this study improved fibre fermentability in the rumen, which allowed ruminal fluid and solid particles to flow rapidly into the post-rumen digestive tracts. As a result, the rumen fill became empty and this promoted the bulls to consume more of the diet. This explanation is consistent with the study of Karsli \& Russell (2001), who reported that an increase in ruminal fluid and flow rate of solid particles into the small intestine enhance feed intake.

Further analyses of DMI responses of the bulls relative to their weight (percentage of BW) and metabolic weight (g DM/kg BW ${ }^{0.75}$ ) showed similar DMI responses in all yearling bulls in the current study. Differences in DMI in yearling bulls were in proportion with the differences in their BW and physiological state. The DMI range in the current study $(2.23-2.27 \% \mathrm{BW})$ was similar to that of bulls $(2.1-3 \% \mathrm{BW})$ reported by Galina et al. (2003) and steers (2.13-2.26\% BW) reported by Chizzotti et al. (2008).

Changes in nutrient intake as a result of experimental treatments followed the changes in feed intake patterns. In addition, nutrient composition fluctuated less across the experimental diets. This allowed nutrient intake to follow the feed intake pattern. It was not surprising that $\mathrm{OM}$ and $\mathrm{CP}$ intakes were higher in the $\mathrm{ZnU}$, treatment because its $\mathrm{OM}$ and $\mathrm{CP}$ contents were slightly higher than in the $\mathrm{U}$ treatment. Furthermore NDF and hemicellulose intakes were higher in UZ than in ZnU and ZnUZ treatments, because the levels of NDF and hemicellulose were higher in UZ than in the ZnU and ZnUZ treatments. On the other hand, ADF intake did not change across the experimental rations because ADF levels in the diets were similar.

Galo et al. (2003) reported that when polymer-coated urea substituted urea in a diet, apparent digestibility of DM and CP improved, but ADF digestibility decreased. Taylor-Edwards et al. (2009b) reported that when slow-release urea substituted urea, the apparent digestibility of DM, OM, NDF and ADF did not change, but $\mathrm{N}$ digestibility decreased. In the present study, a decrease in NDF or ADF digestibility occurred only when NU was replaced with urea $(U)$. In contrast, when urea was replaced with slow-release urea compounds, fibre (NDF, ADF, cellulose and hemicellulose) digestibility increased, especially with ZnU and UZ. In ruminants, fibre digestion takes place mainly in the rumen, where rumen microbes ferment fibre fractions of ingested feed. For this purpose, rumen microbes require available energy and nitrogen sources in synchronous amounts. Apparently, the energy to $\mathrm{N}$ ratio available to rumen microbes becomes less synchronized when protein $\mathrm{N}$ from plant protein sources (NU) was replaced with urea- $\mathrm{N}$, and this resulted in 
lower fibre (NDF or ADF) digestion. However, in this study, the synchrony of available energy and $\mathrm{N}$ improved when slow-release urea replaced urea because slow-release urea provided $\mathrm{N}$ in continuous supply for rumen microbes, which resulted in improvement of fibre digestibility. This finding could support the observation that slow-release urea compounds improved DMI.

An increase in apparent digestibility of CP when slow-release urea compounds replaced $U$ and $N U$ was probably because these slow-release urea compounds could supply nitrogen continuously in optimum amounts for rumen microbial protein synthesis. As a result, the microbial protein supply to the small intestine increased, followed by an increase in CP digestibility. This increase in apparent CP digestibility was in line with the results of an in vitro study by Kardaya et al. (2010), who reported that in vitro rumen microbial protein synthesis increased when urea was replaced with $\mathrm{ZnU}$, UZ or ZnUZ, combined with 6\% molasses.

It was expected that in vivo DM or OM digestibility would correlate with in vitro values. For this purpose, in vitro DM and OM degradability data (Kardaya et al., 2009) were used. Both in vivo DM and OM digestibility correlated with in vitro DM and OM degradability, respectively, and could best be predicted with linear regression. The equation: $Y_{\text {dmd }}=28.762+0.795 X_{\text {dmd }} ;(r=0.83 ; p=0.03)$, and $Y_{\text {omd }}=44.504+0.453$ $X_{\text {omd }}(r=0.83 ; p=0.03)$, where $Y_{d m d}=$ predicted in vivo dry matter apparent digestibility, $Y_{\text {omd }}=$ predicted in vivo organic matter apparent digestibility; $\mathrm{X}_{\mathrm{dmd}}=$ in vitro dry matter degradability and $\mathrm{X}_{\mathrm{omd}}=$ in vitro organic matter degradability.

The final weight of the bulls after 56 days ranged from 181 to $187 \mathrm{~kg}$ (Table 4). The range was narrower than that reported by Panjaitan et al. (2003), who found that the live weight of 18-month-old Bali bulls was in the range of 146-185 $\mathrm{kg}$. Meanwhile, the ADG of Bali bulls (607-651 $\mathrm{g} / \mathrm{head})$ was higher than that of Sariubang et al. (2002), who reported that the ADG of Bali bulls fed urea-supplemented rice straw combined with rice bran was 370-410 g/head. Apparently, the higher final weight of bulls fed UZ was related to their initial weight, which was slightly higher $(P=0.087)$ than that of bulls fed other experimental diets.

Improved LWG, ADG and feed efficiency when urea-impregnated zeolite (UZ) replacement urea (U) agree with results of a study of Ortiz et al. (2002), who reported that slow intake urea supplement increased $(P<0.05)$ the LWG of Zebu cattle. On the other hand, Taylor-Edwards et al. (2009a) found that polymercoated urea (1.2\% DM) did not significantly increase the LWG of steers. It was suggested that the increase in ADG and feed efficiency of Bali bulls fed UZ in the current study was the result of its slow-release property, which improved ration palatability and nutrient utilization, as reflected in nutrient digestibility. Feeding UZ ration to Bali bulls improved feed efficiency and ADG.

\section{Conclusions}

The inclusion of zinc-urea-impregnated zeolite (ZnUZ) in rice straw-based diets showed slow-release urea characteristics that had positive effects on feed intake, nutrient digestibility, feed efficiency and ADG of Bali bulls.

\section{Acknowledgements}

The authors would like to thank the Directorate General of Higher Education, Research and Technology, Republic of Indonesia and Institution for Research and Service Society, Djuanda University for the research grant.

\section{Authors' Contributions}

DK designed the study, executed the project and analysed data. KGW assisted in the design of the study and data analyses. AP designed the research and HMW edited the draft version of the manuscript.

\section{Conflict of Interest Declaration}

The authors declare that there is no conflict of interest.

\section{References}

AOAC, 1990. Official methods of analysis. 16th edition. Association of Official Analytical Chemists, Arlington, VA, USA.

Bosi, P., Creston, D. \& Casini, L., 2002. Production performance of dairy cows after the dietary addition of clinoptilolite. Italian J. Anim. Sci. 1, 187-195.

Chizzotti, F.H.M., Pereira, O.G., Tedeschi, L.O., Valadares Filho, S.C., Chizzotti, M.L., Leão, M.I. \& Pereira, D.H., 2008. Effects of dietary non protein nitrogen on performance, digestibility, ruminal characteristics, and microbial efficiency in crossbred steers. J. Anim. Sci. 86, 1173-1181.

Forero, O., Owens, F.N., Leme, P. \& Lusby, K.S., 1978. Range studies with a new slow release urea compound. Anim. Sci. Res. Report 2, 25-31.

Galina, M.A., Pe'rez-Gil, F., Ortiz, R.M.A., Hummele, J.D. \& Ørskov, R.E., 2003. Effect of slow release urea supplementation on fattening of steers fed sugar cane tops (Saccharum officinarum) and maize (Zea mays), ruminal fermentation, feed intake and digestibility. Livest. Prod. Sci. 83, 1-11.

Galo, E., Emanuele, S.M., Sniffen, C.J., White, J.H. \& Knapp, J.R., 2003. Effects of a polymer-coated urea product on nitrogen metabolism in lactating Holstein dairy cattle. J. Dairy Sci. 86, 2154-2162. 
Golombeski, G.L., Kalscheur, K.F., Hippen, A.R. \& Schingoethe, 2006. Slow-release urea and highly fermentable sugars in diets fed to lactating dairy cows. J. Dairy Sci. 89, 4395-4403.

Kardaya, D., Supriyati, Suryahadi \& Toharmat, T., 2000. Effect of zinc-proteinate, Cu-proteinate and ammonium molybdate supplements on local sheep performances. Media Peternakan J. Anim. Sci. Technol. 24, 1-9.

Kardaya, D., Wiryawan, K.G., Parakkassi, A. \& Winugroho, H.M., 2009. In vitro slow-release urea characteristics under different molasses levels contained in rice straw based diets. Indonesian J. Anim. Sci. Vet. 14, 177-191.

Kardaya, D., Wiryawan, K.G., Parakkassi, A. \& Winugroho, H.M., 2010. In vitro slow-release urea contained in rice strawbased diets to increase efficiency of rumen microbial protein synthesis. Indonesian J. Anim. Sci. Vet. 15, 111-123.

Karsli, M.A. \& Russell, J.R., 2001. Effects of some dietary factors on ruminal microbial protein synthesis. Turk. J. Vet. Anim. Sci. 25, 681-686.

Kathirvelan, C. \& Balakrishnan, V., 2006. Effect of zinc supplementation on urea hydrolysis in an in vitro fermentation using rumen liquor. Mal. J. Nutr. 12, 93-99.

Koknaroglu, H., Toker, M.T. \& Bozkurt, Y., 2006. Effect of zeolite and initial weight on feedlot performance of Brown Swiss cattle. Asian J. Anim. Vet. Adv. 1, 49-54.

Ludden, P.A., Harmon, D.L., Huntington, G.B., Larson, B.T. \& Axe, D.E., 2000b. Influence of the novel urease inhibitor N(n-butyl) thiophosphoric triamide on ruminant nitrogen metabolism. II. Ruminal nitrogen metabolism, diet digestibility, and nitrogen balance in lambs. J. Anim. Sci. 78, 188-198.

Ludden, P.A., Harmon, D.L., Larson, B.T. \& Axe, D.E., 2000a. Influence of the novel urease inhibitor N-(n-butyl) thiophosphoric triamide on ruminant nitrogen metabolism. I. In vitro urea kinetics and substrate digestion. J. Anim. Sci. 78, 181-187.

Mentz, A.M., Van Niekerk, W.A., Hassen, A., Coertze, R.J. \& Gemeda, B.S., 2015. Effect of diets differing in rumen soluble nitrogen on utilization of poor-quality roughage by sheep. S. Afr. J. Anim. Sci. 45, 528-537.

Migliorati, L., Abeni, F., Cattaneo, M.P., Tornielli, C. \& Pirlo, G., 2007. Effects of adsorbent in dairy cow diet on milk quality and cheese-making properties. Italian J. Anim. Sci. 6 (supplement 1), 460-462.

NRC, 1985. Ruminant nitrogen usage. Subcommittee on Nitrogen Usage in Ruminants. Committee on Animal Nutrition. National Research Council. National Academy of Sciences. National Academy Press, Washington, DC.

Ortiz, R.M.A., Galina, M.A. \& Carmona, M.M.A., 2002. Effect of a slow non-protein nitrogen ruminal supplementation on improvement of Cynodon nlemfuensis or Brachiaria brizanta utilization by Zebu steers. Livest. Prod. Sci. 78, 125-131.

Panjaitan, T., Fordyce, G. \& Poppi, D., 2003. Bali cattle performance in the dry tropics of Sumbawa. Indonesian J. Anim. Sci. Vet 8,183-188.

Robertson, J.B. \& Van Soest, P.J., 1981. The detergent system of analysis and its application to human foods. In: W.P.T. James \& O. Theander (eds). The Analysis of Dietary Fiber in Food. Marcel Dekker, New York, NY.

Sariubang, M., Ella, A., Nurhayu, A. \& Pasambe, D., 2002. A study on integrated beef cattle farming at South Sulawesi. Wartazoa 12, 24-28.

Steel, R.G.D. \& Torrie, J.H., 1980. Principles and Procedures of Statistics. A Biometrical Approach. 2nd edition. McGrawHill, London.

Taylor-Edwards, C.C., Hibbard, G., Kitts, S.E., McLeod, K.R., Axe, D.E., Vanzant, E.S., Kristensen, N.B. \& Harmon, D.L., 2009a. Effects of slow-release urea on ruminal digesta characteristics and growth performance in beef steers. J. Anim. Sci. 87, 200-208.

Taylor-Edwards, C.C., Elam, N.A., Kitts, S.E., McLeod, K.R., Axe, D.E., Vanzant, E.S., Kristensen, N.B. \& Harmon, D.L., $2009 \mathrm{~b}$. Influences of slow-release urea on nitrogen balance and portal-drainage visceral nutrient flux in beef steer. J. Anim. Sci. 87, 209-221.

Van Soest, P.J., Robertson, J.B. \& Lewis, B.A., 1991. Methods for dietary fiber, neutral detergent fiber, and nonstarch polysaccharides in relation to animal nutrition. J. Dairy Sci. 74, 3583-3590. 